\title{
Lignocaine for Topical Anesthesia in Fiberoptic Bronchoscopy
}

\author{
David R. Sanderson \\ Mayo Medical School, Mayo Clinic, Scottsdale, Ariz., USA
}

Fiberoptic bronchoscopy is widely employed by chest physicians around the world and enjoys a remarkable record of safety in a broad spectrum of patiens with a variety of clinical problems. Whether the bronchofiberscope is introduced transorally or transnasally, topical anesthesia is well tolerated. Cocaine, benzocaine, tetracaine, and lignocaine (lidocaine) can be equally effective, but lignocaine has the widest margin of safety and is most commonly used. Ease of administration and low toxicity permit effective diagnostic and therapeutic applications of this important procedure [1].

In a study published in this issue of Respiration by Loukides et al. [2], doses of lignocaine were tabulated and plasma levels measured during and after bronchoscopy in 12 adult patients. $2 \%$ lignocaine gel was used intranasally and $2 \%$ lignocaine solution was instilled on the larynx and into the trachea in total dose ranging from 500 to $720 \mathrm{mg}$ with the majority being delivered through the bronchoscope. None of their subjects had significant liver disease or heart failure. They measured serum levels of lignocaine at frequent intervals over $2 \mathrm{~h}$ and correlated these with delivered dosage. None of their subjects had any adverse reaction, and blood levels in all were maintained well below the range of 5 or $6 \mu \mathrm{g} / \mathrm{ml}$ thought to be the toxic threshold. Their results suggested that absorption is less or slower with the nasal gel than with the solution instilled through the bronchoscope. With bronchoscopic delivery,

\begin{tabular}{ll}
\hline KARGER & ( 2000 S. Karger AG, Basel \\
0025-7931/00/0671-0009\$17.50/0 \\
$\begin{array}{l}\text { Fax +4161306 1234 } \\
\begin{array}{l}\text { E-Mail karger@karger.ch } \\
\text { www.karger.com }\end{array}\end{array}$ & $\begin{array}{l}\text { Accessible online at: } \\
\text { www.karger.com/journals/res }\end{array}$
\end{tabular}

lignocaine can reach terminal bronchioles and alveoli and rapidly enter the circulation.

Lignocaine is an aminoethylamide that is distributed in the circulation and metabolized almost exclusively in the liver. In patients with normal liver function, the halflife of the drug is 100-120 $\mathrm{min}$ [3]. Clearance may also be decreased in patients with congestive heart failure. The manufacturers' guidelines emphasize dosage limits. For lidocaine hydrochloride topical solution USP 4\%, Roxane Laboratories, Inc., recommend that the maximum dose be 'kept below $300 \mathrm{mg}$ and in any case should never exceed $4.5 \mathrm{mg} / \mathrm{kg}(2 \mathrm{mg} / \mathrm{lb})$ of body weight' [4]. For intravenous injection, which is similar to alveolar instillation, Astra Pharmaceutical USA, Inc., recommend that 'no more than 200 to $300 \mathrm{mg}$ of lidocaine hydrochloride should be administered during a one hour period' [5].

Although lignocaine has an enviable safety record, toxic reactions have been reported, usually associated with higher delivered doses or impaired clearance. Wu et al. [6] reported that in a seriously ill 30-year-old woman with acquired immunodeficiency syndrome (AIDS) and chronic renal failure, seizures developed after a total dose of lignocaine of 300-320 mg. Her serum lignocaine level shortly after the seizure was $12.0 \mu \mathrm{g} / \mathrm{ml}$ and was still increased at $7.6 \mu \mathrm{g} / \mathrm{ml} 4 \mathrm{~h}$ later. Day et al. [7] reported on the use of lignocaine in a previously healthy 19 -year-old female student who was a volunteer in a research investi-
David R. Sanderson, MD

Professor of Medicine, Mayo Medical School

Mayo Clinic Scottsdale

Scottsdale, AZ 85259 (USA)

Tel. +1 602301 8265, Fax +1 6023014869 
gation into the function of lung cells. No accurate tabulation of the dose of lignocaine was described, but it was noted that 'she required considerable amounts of spray to decrease discomfort'. She subsequently had a seizure followed by cardiac arrest and died 2 days later. A blood sample drawn $3 \mathrm{~h}$ after bronchoscopy showed a serum lignocaine level of $12.9 \mu \mathrm{g} / \mathrm{ml}$. The authors estimated that she may have received as much as $1,200 \mathrm{mg}$ of lignocaine. Bronchospasm is uncommon during bronchoscopy, but bronchoconstriction was found in 5 of 20 asthmatic patients who received inhalation of nebulized $4 \%$ lignocaine solution [8].
The report by Loukides et al. demonstrates that higher doses of lignocaine can be well tolerated in a generally healthy population. But as with all procedures in medicine and surgery, safety for patients is of paramount importance. Physicians must be aware of the side effects of all the drugs they use and seek to avoid complications whenever possible while being prepared to deal with those that may occur. Prudence dictates that the bronchoscopist be sensitive to the amount of topical agent administered and expected clearance rate in individual patients. Monitoring dosage and limiting to minimum amounts required for patient comfort will assure continued safe outcomes.

\section{References}

1 Ereth MH, Stutts SE, Lennon RL: Bronchoscopic pharmacology and anesthesia; in Prakash UBS (ed): Bronchoscopy. New York, Raven Press, 1994, pp 91-104.

2 Loukides S, Katsoulis K, Tsarpalis K, Panagou $\mathrm{P}$, Kalogeropoulos N: Serum concentrations of lignocaine before, during and after fiberoptic bronchoscopy. Respiration 2000;67:13-17.
3 Catterall WA, Mackie K; in Goodman \& Gilman's, The Pharmacologic Basis of Therapeutics, ed 9. New York, McGraw-Hill, 1996, pp 338, 1754.

4 Lidocaine hydrochloride topical solution USP 4\%, Package insert, Roxane Laboratories Inc., Oct 1996.

5 Xylocaine (lidocaine $\mathrm{HCl}$ Injection, USP) Package insert, Astra USA, Inc., Feb 1995.

6 Wu FL, Razzaghi A, Souney PF: Seizure after lidocaine for bronchoscopy: Case report and review of the use of lidocaine in airway anesthesia. Pharmacotherapy 1993;31:72-78.
7 Day RO, Chalmers DR, Williams KM, Campbell TJ: The death of a healthy volunteer in a human research project: Implications for Australian clinical research. Med J Austr 1998;168: 449-451.

8 McAlpine LG, Thomson NC: Lidocaine-induced bronchoconstriction in asthmatic patients. Chest 1989;96:1012-1015. 